\title{
A new species of Chaetopterus (Annelida: Chaetopteridae) from eastern Canada, with a redescription of Chaetopterus norvegicus M. Sars, 1835
}

\author{
Jenna M. MOORE ${ }^{1, *}$, Jean-Marc GAGNON ${ }^{2}$ \& Mary E. PETERSEN ${ }^{3, \dagger}$ \\ ${ }^{1}$ Florida Museum of Natural History, University of Florida, Dickinson Hall, \\ 1659 Museum Road, Gainesville, FL 32611, USA. \\ ${ }^{1}$ Department of Invertebrate Zoology, Smithsonian National Museum of Natural History, \\ MRC-163, P.O. Box 37012, Washington, DC, 20013-7012, USA. \\ ${ }^{2}$ Research \& Collections Division, Canadian Museum of Nature, P.O. Box 3443, \\ Station D, Ottawa, ON K1P 6P4, Canada. \\ ${ }^{3}$ Former address: Darling Marine Center, University of Maine, 193 Clark's Cove Road, \\ Walpole, Maine, 04573-3307, USA. \\ *Corresponding author: jennamoore.work@gmail.com \\ 2Email: JMGAGNON@nature.ca \\ ${ }^{1} \odot$ https://orcid.org/0000-0003-0546-7833 \\ 2 (i) https://orcid.org/0000-0003-2778-4215 \\ ${ }^{1}$ urn:lsid:zoobank.org:author:76A3E85C-945B-41CB-A4E8-5E8082BF95AA \\ ${ }^{2}$ urn:lsid:zoobank.org:author:04D0758C-A048-42CA-8D47-201219A30164 \\ ${ }^{3}$ urn:lsid:zoobank.org:author:568509A5-6B87-43F7-9DCD-BD44CFF25436
}

\begin{abstract}
Chaetopterus is a globally distributed genus of marine Annelida with a long history of taxonomic confusion. Here, we describe Chaetopterus bruneli sp. nov. from a depth of $350 \mathrm{~m}$ in the St. Lawrence Estuary, eastern Canada. The new species represents the northernmost record for Chaetopterus in the western Atlantic to date. The similar European species Chaetopterus norvegicus M. Sars, 1835 is resurrected from long-standing synonymy and redescribed from type material, and a lectotype is designated.
\end{abstract}

Keywords. Chaetopterus bruneli sp. nov., St. Lawrence Estuary, North Atlantic, systematics, taxonomy.

Moore J.M., Gagnon J.-M. \& Petersen M.E. 2020. A new species of Chaetopterus (Annelida: Chaetopteridae) from eastern Canada, with a redescription of Chaetopterus norvegicus M. Sars, 1835. European Journal of Taxonomy 720: 19-34. https://doi.org/10.5852/ejt.2020.720.1111

\section{Introduction}

Chaetopteridae Audouin \& Milne-Edwards, 1833 is a globally distributed family of marine Annelida Lamarck, 1809, and currently comprises 73 valid species in four genera (Britayev \& Martin 2019; Read \& Fauchald 2019; Tilic \& Rouse 2020). The genus Chaetopterus Audouin \& Milne-Edwards, 1833 was 
established for C. pergamentaceus Cuvier, 1830, a large, infaunal, tube-dwelling annelid described from the Caribbean Sea. Members of the genus Chaetopterus have the most extreme notopodial specialization among chaetopterids, with all benthic species sharing a highly conserved complement of specialized, modified notopodial structures for single mucus net suspension feeding in the middle body region. The uniformity of their unusually tagmatized body plan, coupled with a flexible capacity for anterior and posterior regeneration (Berrill 1928), contributes to difficulty in distinguishing among species on the basis of morphology alone.

The genus Chaetopterus was first revised by Joyeux-Laffuie (1890), who regarded most European representatives as belonging to Chaetopterus variopedatus (Renier 1804). Subsequent authors expanded this view to eventually place all species of Chaetopterus from the North Atlantic, Indo-Pacific, and Antarctic under C. variopedatus, as a single, highly variable and cosmopolitan species (Crossland 1904; de St. Joseph 1894; Fauvel 1927). Recent phylogenetic studies provide evidence that the genus is far more diverse than reflected in the current taxonomy (Osborn et al. 2007; Zhang et al. 2015; Moore et al. 2017). While several Pacific species have been resurrected from synonymy (Nishi 2001), most species remain synonymized with $C$. variopedatus.

There are nine nominal species of Chaetopterus described from North Atlantic and Mediterranean waters; however, only C. pergamentaceus and C. variopedatus are currently considered valid (Read \& Fauchald 2019). While both C. pergamentaceus and C. variopedatus are large, infaunal species, there are several epifaunal species names currently synonymized under $C$. variopedatus. One of these, Chaetopterus norvegicus M. Sars, 1835, was described from the Bergen fjord in western Norway, and is a longstanding junior synonym of C. variopedatus (Joyeux-Laffuie 1890; de St. Joseph 1894; Fauvel 1927). Despite this status, some recent workers have published records that recognized $C$. norvegicus from the northeastern Atlantic, from western Sweden in the east (GBIF 2019) and west to the Faroe Islands Shelf at $250 \mathrm{~m}$ (Jensen \& Frederiksen 1992).

In the western North Atlantic, Chaetopterus pergamentaceus has been recorded as far north as Cape Cod (GBIF 2019). During benthic sampling of the St. Lawrence Estuary in eastern Canada in 1991 and 1992, 18 specimens of a very small, epibenthic Chaetopterus were found on soft substrates at a depth of $350 \mathrm{~m}$, representing the northernmost record of the genus in the western North Atlantic. These specimens most closely resemble C. norvegicus; however, several morphological and ecological features distinguish these taxa. The Canadian specimens are newly described below as Chaetopterus bruneli sp. nov. Chaetopterus norvegicus is resurrected from synonymy and redescribed from original syntype material, and a lectotype is designated.

\section{Material and methods}

\section{Collections}

The holotype and 17 paratypes of Chaetopterus bruneli sp. nov. are deposited in the annelid collections of the Canadian Museum of Nature, Ottawa (18 specimens, CMNA 2015-0001 to CMNA 2015-0018). These specimens were collected by the second author, using a $0.2 \mathrm{~m}^{2}$ box corer, from fine silt and sand sediments at a depth of $350 \mathrm{~m}$ in the St. Lawrence Estuary (Station 23, 48 $42.20^{\prime} \mathrm{N}, 68^{\circ} 33.98^{\prime} \mathrm{W}$ ), during seven sampling events from February 1991 to October 1992. A total of 52 samples were brought up to the surface, undisturbed, and transported to the laboratory as described in Silverberg et al. (1995). There, the benthic communities were maintained alive in mesocosms where specimens of Chaetopterus could be observed under a stereo microscope. Eighteen specimens were maintained alive during the mesocosm experiments and relaxed by gradually adding drops of $70 \%$ ethanol before fixation in a $4 \%$ buffered formaldehyde solution, then washed in freshwater and transferred to $70 \%$ ethanol for long-term preservation. 


\title{
Terminology
}

The chaetopterid body plan is unique among annelids for its division into three distinct, functionally specialized body regions (tagmata). Following Crossland (1904), we refer to these anterior, middle and posterior tagmata as A, B and C, respectively. Counting of chaetigers is done within each tagma; e.g., A1-A9 refer to chaetae-bearing segments 1-9 of the anterior tagma. A-last refers to the last chaetiger in tagma $\mathrm{A}$, as the number of segments can vary within this tagma.

\section{Morphological observations}

Preserved specimens were examined, measured, and photographed at 7.1-25X magnification using a Leica stereo microscope mounted with a Nikon D7000 DSLR camera. To characterize notochaetal features, A4 parapodia were dissected and mounted whole on glass microscope slides in Canada balsam and photographed using the camera above mounted on a Leica compound microscope. Uncini-bearing tissues were sampled from A9 neuropodia (if present), the anterior and posterior neuropodial lobes of B1, ventral lateral tori of B3, and ventral and lateral lobes of C1. Uncini were teased away from surrounding tissue using fine needles and mounted on microscope slides in Euparal. Measurement data were collected from compound light micrographs. Drawings of specimens were made from photographs to illustrate selected structures for comparison.

\author{
Abbreviations \\ CMNA $=$ Canadian Museum of Nature, Gatineau, QC, Canada \\ LACM $=$ Natural History Museum of Los Angeles County, USA \\ NHMO = Natural History Museum, University of Oslo, Norway \\ $\mathrm{UF} \quad=$ Florida Museum of Natural History, University of Florida, USA \\ USNM $=$ US National Museum of Natural History, USA
}

\section{Results}

Phylum Annelida Lamarck, 1809

Family Chaetopteridae Audouin \& Milne-Edwards, 1833

Genus Chaetopterus Cuvier, 1830

Chaetopterus norvegicus $\mathrm{M}$. Sars, 1835, reinstated

Figs 1, 3A

Chaetopterus norvegicus M. Sars, 1835: 54-58, pl. 11, Fig. 29a-h.

Chaetopterus norvegicus - Ørsted 1844: 78; 1845: 414. - McIntosh 1857: 126. - M. Sars 1860: 86. — Danielssen 1861: 52. — Quatrefages 1866: 214. — Malmgren 1867: 88. — G.O. Sars 1873: 261. - Jensen \& Frederiksen 1992: 66.

Tricoelia norvega - Meneghini 1847: 38.

Chaetopterus variopedatus - Joyeux-Laffuie 1890: 345-351. — Lo Bianco 1893: 35. — de SaintJoseph 1894: 148. — McIntosh 1915: 120. — Fauvel 1927: 77-78.

non Tricoelia variopedata Renier, 1804: 18.

\section{Diagnosis}

Small- to medium-bodied, epifaunal Chaetopterus inhabiting a pale cream to brown, laminated, straight or bent tube. Segmental distribution $9 \mathrm{~A}+5 \mathrm{~B}+7-12 \mathrm{C}$. Last segment of region A bearing neuropodia. Parapodia of B1 not posteriorly displaced from segment A-last. Segment B2 short, dorsal surface not fleshy. B1 and B2 neuropodia with four completely unfused, discrete lobes. With 5-10 relatively 
large light brown cutting notochaetae on segment A4, in a conspicuous ventral fascicle. Uncini tooth distribution as follows: A9 with 6-9 teeth, B1 anterior lobe with 7-9, B1 posterior lobe with 6-8, $\mathrm{B} 3$ piston tori with 7-9, B3 ventral lobes and $\mathrm{C} 1$ lateral lobes with $6-9, \mathrm{C} 1$ ventral lobes with $8-12$ teeth.

\section{Material examined}

Lectotype (here designated)

NORWAY • one complete specimen preserved within tube fragment; Bergensfjord; depth 30-60 fathoms [54-110 m]; from original syntype lot NHMO C5877; NHMO C7049.

Paralectotypes (here designated)

NORWAY $\bullet 8$ fragments and tube fragments; same collection data as for lectotype; from original syntype lot; NHMO C5877.

\section{Other material}

NORWAY - 4 fragments; Hardangersfjord, Rute H05-59; depth 30-42 m; 21 Oct 1958; LACM uncataloged specimens Pol2 Z76/58.

\section{Additional known material}

The following specimens were examined and identified as Chaetopterus norvegicus by M.E. Petersen; however, their current location was not verified or ascertained. We include them here to contribute additional distributional information for this species:

SWEDEN • 1 spec.; Gullmarfjord, Humlesäcken; depth 30-50 m; 17 Sep. 1984; Claus Nielsen leg., from dredged material housed at the Kristineberg Marine Station - 3 specs; Gullmarfjord, Ösö Holme; depth 37-40 m; 16 Sep. 1969; Claus Nielsen leg.; stones and shells.

DENMARK • 3 specs; Herthas Flak; depth 15-20 m; 19 Jun. 1971.

\section{Description}

Based mostly on lectotype and paralectotypes. Uncini data based on LACM specimens, and their tooth counts and measurements are given in Table 1.

Gross morphology and presegmental structures. Small to medium-sized epibenthic Chaetopterus, $26 \mathrm{~mm}$ total body length for 26 chaetigers in lectotype, segmental formula $9 \mathrm{~A}+5 \mathrm{~B}+7-12 \mathrm{C}$. Peristomium ventrally broad, horseshoe-shaped in dorsal view, with broad dorsolateral lobes that sometimes obscure A1 notopodia, sometimes with medium-brown pigment on dorsal surface. Grooved palps short, thin and filiform, inserted at dorsal inner margins of peristomium, $1.5 \mathrm{~mm}$ in length $(\mathrm{n}=5)$. Eyes small, faint black spots positioned laterally near the outer base of the palps and obscured by the laterodorsal lobes of the peristomium.

Region A. Anterior region with 9 segments (Fig. 1A); $4.9 \mathrm{~mm}$ mean length (range 4.5-6 mm, $\mathrm{n}=6$ ) and $4.5 \mathrm{~mm}$ mean width (range 3-6 mm, $\mathrm{n}=6$ ), slightly longer than wide or as wide as long; ventral surface of A with broad, rectangular glandular shield (Figs 1B, 3A). Region A notopodia shortest at $\mathrm{A} 1$ or A4, increasing from A4 to a maximum at A6 and decreasing in length again to segment A9; A4 notopodia shorter than neighboring notopodia. Small swellings not visible at dorsal base of A notopodia. Segment A4 notopodia bearing 5-10 relatively large apically blunt, light brown, cutting chaetae, with a distinct ventral tooth, on the ventral side of the notopodia (Fig. 1A). Other notopodia and the distal side of A4 notopodia bear lanceolate and simple chaetae. Region A chaetigers uniramous except the last, A9, also with fan-shaped neuropodia in 4 of 5 specimens; mean width $1.3 \mathrm{~mm}$ (range $1-1.5 \mathrm{~mm}, \mathrm{n}=4$ ) and furnished with uncini on posterior margin (Figs 1B, 3A). A9 uncini asymmetrically pyriform to 

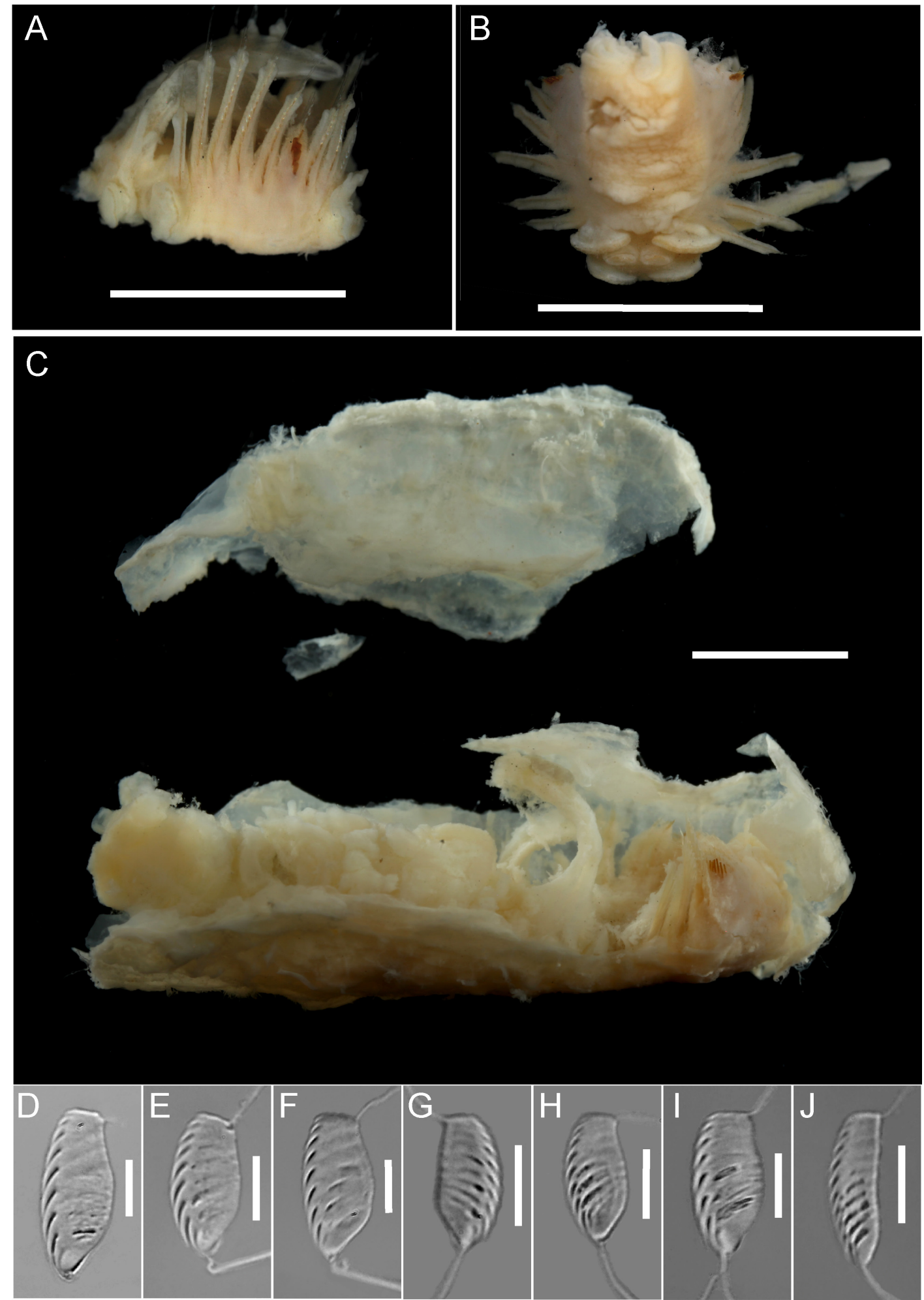

Fig. 1. Chaetopterus norvegicus M. Sars, 1835. A. Right lateral view of anterior fragment of a paralectotype NHMO C5877 (to segment B1). B. Ventral view of anterior fragment of a paralectotype NHMO C5877 (to segment B1). C. Top, tube fragment, bottom, lectotype specimen NHMO C7049 preserved within a fragment of tube. D-J. Uncini sampled from non-type, uncataloged LACM specimen Pol2 Z76/58. D. Uncinus of A9 neuropodium. E. Uncinus of B1 anterior neuropodial lobe. F. Uncinus of B1 posterior lobe. G. Uncinus of B3 piston torus. H. Uncinus of B3 ventral lobe. I. Uncinus of C1 lateral lobe. J. Uncinus of $\mathrm{C} 1$ ventral lobe. Scale bars: A-C $=5 \mathrm{~mm}$; D-J $=20 \mu \mathrm{m}$. 
Table 1. Comparative morphological data summary of Chaetopterus norvegicus M. Sars, 1835 and C. bruneli sp. nov. Segment numbers follow conventional counting within tagmata A, B and C for Chaetopteridae Audouin \& Milne-Edwards, 1833. A-last = the last chaetiger in tagma A; lat. = lateral.

\begin{tabular}{lcc}
\hline Character & $\begin{array}{c}\text { Chaetopterus norvegicus } \\
\text { M. Sars, 1835 }\end{array}$ & Chaetopterus bruneli sp. nov. \\
\hline Eyes & present & absent \\
Peristomium pigmented & absent in alcohol & absent in alcohol \\
Segments tagma A & 9 & $9-10$ \\
Segments tagma B & 5 & 5 \\
Segments tagma C & $7-12$ & $4-6$ \\
No. A4 cutting chaetae & $5-10$ & $3-8$ \\
Color of cutting chaetae & light brown & gold \\
Shortest A notopodia & A1 or A4 & A1 or A9 \\
Longest A notopodia & A6 & A5 or A6 \\
A-last bearing neuropodia & present & absent \\
B1 neuropodia lobe fusion & unfused & unfused \\
Shape of C notopodia & narrow, tapered distally & club-shaped \\
C lat. neuropodia cirri & absent & absent \\
\hline
\end{tabular}

D-shaped, apically blunt and pointed at base, widest at middle or slightly below, with a curved proximal margin (Fig. 1D).

REGion B. Middle body region $10 \mathrm{~mm}$ in length in complete specimen. B1 with long aliform notopodia, $6 \mathrm{~mm}$ mean length (range 5-7 mm, $\mathrm{n}=6$ ), reaching anteriorly to the peristomium (Fig. 1A-B). B1 and B2 neuropodia bilobed, with four completely unfused, discrete lobes, with uncini on distal lobe margins (Figs 1B, 3A). Anterior pair of neuropodial lobes in B1 narrow and situated medially (Figs 1B, $3 \mathrm{~A}$ ); uncini ovate to D-shaped, sometimes slightly pyriform, apically blunt and pointed or rounded at base, widest at middle or slightly below (Fig. 1E). Posterior neuropodial lobes of B1 broader than anterior and situated laterally (Figs 1B, 3A); uncini asymmetrically pyriform to ovate, apically blunt and pointed or rounded at base, widest at middle or slightly below, with a curved proximal margin (Fig. 1F). Segment B2 relatively short, $5 \mathrm{~mm}$ in length in one posterior fragment specimen; neuropodia bilobed with four completely unfused, discrete lobes; anterior pair of neuropodial lobes situated more laterally than posterior pair. Neuropodia of B3-B5 with a single pair of short, medially fused and ridge-like lobes, bearing uncini on posterior margins. B3 uncini of piston tori ovate to D-shaped, apically blunt and pointed at base, widest at middle, with straight proximal margin (Fig. 1G). B3 ventral lobe uncini asymmetrically pyriform to D-shaped, apically blunt and pointed at base, widest at middle or slightly below, with straight proximal margin (Fig. 1H).

Region C. Posterior body region mean length $6 \mathrm{~mm}$ (range 2-10 mm, $\mathrm{n}=4$ ), with $7-12$ chaetigers. Region $\mathrm{C}$ notopodia long and thin, tapering evenly to apex; $\mathrm{C} 1$ notopodia mean length $3.3 \mathrm{~mm}$ (range $2.5-4.5 \mathrm{~mm}, \mathrm{n}=4$ ). Neuropodia bilobed, ventral lobes medially unfused, $\mathrm{C} 1$ ventral neuropodial lobes broader than those in succeeding segments; lateral lobes of $\mathrm{C}$ neuropodia lacking dorsal and ventral cirri, one specimen with small dorsal inflations on dorsal margin of lateral lobes. Both neuropodial lobes bear a row of uncini on distal margin. C1 lateral lobe uncini asymmetrically pyriform to D-shaped, apically blunt and pointed at base, widest at middle or slightly below, with straight or curved proximal margin (Fig. 1I). C1 ventral lobe uncini long D-shaped, apically blunt and pointed or rounded at base, widest at middle, sometimes with marked curvature toward proximal side (Fig. 1J). 
MOORE J.M. et al., Chaetopterus bruneli sp. nov. (Annelida) from eastern Canada

TUBE. Tube straight or irregularly bent, pale cream-white and paper-like, very thin and delicate, composed of laminated proteinaceous material, without externally affixed sediment (Fig. 1C).

\section{COI barcode sequence}

GenBank ID DQ209254 (Osborn et al. 2007), as Chaetopterus sarsi M. Sars, 1860, from Trondheimsfjord, Norway, SAM E3557. Included in BOLD Barcode Index Number BOLD: AAW6559, identified from photographs.

\section{Ecology and distribution}

Chaetopterus norvegicus is an epifaunal species found on rocky substrates, sometimes among the branches of the coral Desmophyllum pertusum (Linnaeus, 1758) (Malmgren 1867, as Lophelia prolifera; Ørsted 1845, as Oculina prolifera; Jensen \& Frederiksen 1992, as Lophelia pertusa), from depths of 30 $550 \mathrm{~m}$. Chaetopterus norvegicus was recorded as a prey item of haddock, Melanogrammus aeglefinus (Linnaeus, 1758) by McIntosh (1857). Little else is known about its ecology.

Reported from the North Sea and Arctic waters, west to the Faroe Islands (Jensen \& Frederiksen 1992), with the northernmost reports from Karlsö, near Tromsø in northern Norway; widespread in coastal Norway, including areas near Bergen, Oslo, and Trondheim; Koster, Väderöarma and Gullmann in western Sweden, south to Kattegat (Malmgren 1867); not known from the Baltic Sea.

\section{Remarks}

The lectotype is delicate and in fair condition, and represents the sole complete specimen within the original syntype lot. The paralectotypes consist of the remaining original syntypes and are in a similar condition. To avoid destructive sampling of the original type material, we examined uncini from a Norwegian specimen in the collections of the LACM. The external morphological features of this specimen agree with those of the lectotype and paralectotypes. Three additional specimens of Chaetopterus norvegicus from Denmark and western Sweden were examined and figured in detail by the late M.E. Petersen (see Additional known material, above). The present location of these specimens is unknown, but the notes and drawings agree well with the features present in the type material.

Chaetopterus norvegicus M. Sars, 1835 was the second species described within the genus Chaetopterus. The original description of Chaetopterus norvegicus is detailed and includes illustrations; however, Sars mistook the dorsal side for the ventral, and included segment B1 in the anterior body region, as first remarked by Quatrefages (1866). Sars noted the apparent absence of eyes in C. norvegicus in his description; however, lateral eyespots appear in his later, unpublished figures of C. norvegicus (M. Sars ca 1870) and are faintly visible in the type specimens.

Prior to this study, eight nominal species of Chaetopterus had been described from the North Atlantic, including the Caribbean, Mediterranean, and North Seas: C. variopedatus (Renier 1804), C. pergamentaceus Cuvier, 1830, C. norvegicus M. Sars, 1835, C. sarsii Boeck in Sars, 1860, C. insignis Baird, 1864, C. valencinii Quatrefages, 1866, C. quatrefagesi Jourdain, 1868, and C. brevis Lespés, 1872. Chaetopterus norvegicus is readily distinguishable from other North Atlantic species by its unfused neuropodia in segments B1 and B2, a character clearly shown in Sars' figures (M. Sars 1835, ca 1870). All other species of Chaetopterus previously described from the North Atlantic possess fused, sucker-like neuropodia in segments B1 and B2 (but see below).

The most recent phylogenetic analysis of the family recovered C. norvegicus in a clade including C. pugaporcinus Osborn, Rouse, Goffredi \& Robison, 2007 and C. antarcticus Kinberg, 1866 (Moore et al. 2017; C. norvegicus is misidentified there as C. sarsii). This clade is sister to all other species of 
Chaetopterus, including C. variopedatus. Thus, genetic evidence does not support the long-standing synonymy of $C$. norvegicus with $C$. variopedatus.

Additionally, several morphological features distinguish between these species. While the original description of C. variopedatus is brief and without figures (Renier 1804), the examination of six specimens of C. variopedatus from the Mediterranean and Adriatic Seas (USNM 5102, UF 4254 to UF 4258) revealed several characters clearly distinguishing these species. Chaetopterus variopedatus has a body size of 7-14 cm, medially fused, bilobed, sucker-like neuropodia in segments B1 and B2, and over 20 segments in tagma C. Furthermore, C. variopedatus secretes a large $(\sim 30 \mathrm{~cm})$, infaunal tube of heavily laminated, flexible, brown parchment-like material covered externally in coarse sediment. Chaetopterus norvegicus, in contrast, has a body size of approximately $2-3 \mathrm{~cm}$, distinctive unfused bilobed neuropodia in segments $\mathrm{B} 1$ and $\mathrm{B} 2,7-12$ chaetigers in tagma $\mathrm{C}$, and inhabits a relatively small, stiff, delicate and somewhat translucent white tube, and is epifaunal on hard substrates. The unusual unfused neuropodia of B1 in C. norvegicus contrast with the sucker-like, fused neuropodia found in C. variopedatus and other species of Chaetopterus (Fig. 3). These strong genetic, morphological and ecological differences warrant the resurrection of $C$. norvegicus as a valid species.

Chaetopterus bruneli sp. nov.

urn:1sid:zoobank.org:act:A18C3F2E-B79B-4617-9E06-E1C665C9729A

Figs 2, 3B

\section{Diagnosis}

Small, epifaunal Chaetopterus inhabiting a pale cream to tan, laminated, crescent-shaped tube. Segmental distribution 9A+5B+4-6C. Neuropodia absent in region A. Parapodia of B1 not posteriorly displaced from segment A-last. Segment B2 short, dorsal surface not fleshy. B1 and B2 neuropodia with four completely unfused, discrete lobes. With 3-8 small, light brown cutting notochaetae on segment A4, in an inconspicuous ventral fascicle. Uncini tooth distribution as follows: A9 neuropodia absent, B1 anterior lobe with 6-8 teeth, B1 posterior lobe with 5-7, B3 piston tori with 5-6, B3 ventral lobes with 5 teeth, $\mathrm{C} 1$ lateral lobes with $6-7, \mathrm{C} 1$ ventral lobes with $8-10$ teeth.

\section{Etymology}

This species is named in honour of Dr. Pierre Brunel, Université de Montréal, who has made a significant contribution to the study of deep-water benthic invertebrate communities in the Estuary and Gulf of St. Lawrence (EGSL) during his career. The specific epithet is a noun in the genitive case.

\section{Material examined}

Holotype

CANADA - St. Lawrence Estuary, epifaunal on surface of muddy sediment; $48.7033^{\circ} \mathrm{N}, 68.5663^{\circ} \mathrm{W}$; depth 350 m; 13 May 1992, Jean-Marc Gagnon leg.; CMNA 2015-0016.

\section{Paratypes}

CANADA - 10 specs; same collection data as for holotype; CMNA 2015-0001 to CMNA 2015-0004, CMNA 2015-0011 to CMNA 2015-0015, CMNA 2015-0017 - 3 specs; same collection data as for holotype; 1 Nov. 1990; CMNA 2015-0005 to CMNA 2015-0007 • 3 specs; same collection data as for holotype; 16 May 1991; CMNA 2015-0008 to CMNA 2015-0010 • 1 spec.; same collection data as for holotype; 15 Oct. 1993; CMNA 2015-0018. All type specimens and associated slide preparations are deposited in the Canadian Museum of Nature. 


\section{Description (holotype)}

Mean and range values are given in parentheses for the holotype and six paratypes. Uncini data are based on paratype specimen CMNA 2015-0018, and their tooth counts and measurements are given in Table 1.

Gross morphology and PReSegmental Structures. Small, epibenthic Chaetopterus, $10.5 \mathrm{~mm}$ total body length for 19 chaetigers (mean $11.6 \mathrm{~mm}$, range $8.0-15.0 \mathrm{~mm}, \mathrm{n}=7$ ); segmental formula $9-10 \mathrm{~A}+5 \mathrm{~B}+5-$ 6C. Peristomium ventrally narrow, horseshoe-shaped in dorsal view, with narrow dorsolateral lobes that sometimes obscure A1 notopodia, without pigment in preserved specimens. Grooved palps short and stout, inserted at dorsal inner margins of peristomium, $2.1 \mathrm{~mm}$ in length (mean $2.1 \mathrm{~mm}$, range $2.0-2.5 \mathrm{~mm})$. Eyes absent.

REGiON A. Anterior region with 9 segments (Fig. 2A; 10 chaetigers on one side in paratype CMNA 2015-0005); $3.0 \mathrm{~mm}$ in length (mean $3.2 \mathrm{~mm}$, range $2.0-4.0 \mathrm{~mm}, \mathrm{n}=7$ ) and $4.0 \mathrm{~mm}$ in width (mean $4.5 \mathrm{~mm}$, range $3.5-5.5 \mathrm{~mm}, \mathrm{n}=7$ ), wider than long. Ventral surface of A with broad, triangular glandular shield, widest anteriorly and narrowing posteriorly to A9 (Fig. 2B). Region A notopodia shortest at A1 or A9, longest at A5 or A6 and decreasing in length again to segment A9; A4 notopodia shorter than neighboring notopodia. Small swellings not visible at dorsal base of A notopodia. Segment A4 notopodia bearing 3-8 relatively small, apically blunt translucent yellow cutting chaetae, with a distinct ventral tooth, on the ventral side of the notopodia (Fig. 2C). Other notopodia and the distal side of A4 notopodia bear lanceolate and simple chaetae (Fig. 2C). Region A chaetigers uniramous, A9 without neuropodia or uncini (Figs 2B, 3B).

ReGion B. Middle body region $6 \mathrm{~mm}$ in length (mean $5.9 \mathrm{~mm}$, range 4.5-7.0 mm, $\mathrm{n}=7$ ). B1 with long aliform notopodia, approximately the length of region A $(2.0-4.0 \mathrm{~mm})$, reaching anteriorly to the peristomium (Fig. 2A). B1 and B2 neuropodia bilobed, with four completely unfused, discrete lobes, with uncini on distal lobe margins (Figs 2B, 3B). Anterior pair of neuropodial lobes in B1 narrow and situated medially (Figs 2B, 3B); uncini pyriform to D-shaped, apically rounded and pointed or rounded at base, widest slightly below middle (Fig. 2E). Posterior neuropodial lobes of B1 broader than anterior lobes and situated laterally (Figs 2B, 3B), uncini ellipsoid to D-shaped, apically blunt and rounded and pointed at base, widest at middle or slightly below (Fig. 2F). Segment B2 short relative to total body length; neuropodia bilobed with four completely unfused, discrete lobes; anterior pair of lobes situated more laterally than posterior pair of lobes (Fig. 2B). Neuropodia of B3-B5 each with a single pair of well-developed, unfused lobes, bearing uncini on posterior margins. Uncini of B3 piston tori ellipsoid to pyriform, apically rounded and rounded or pointed at base, widest at middle, proximal margin sometimes with a medial notch (Fig. 2G). B3 ventral lobe uncini ellipsoid to pyriform, apically blunt and pointed at base, widest at middle or slightly below, proximal margin with a medial notch (Fig. $2 \mathrm{H}$ ).

Region C. Posterior body region $1.5 \mathrm{~mm}$ in length (range $1.5-4.0 \mathrm{~mm}, \mathrm{n}=7$ ), with 4-6 chaetigers. Region $\mathrm{C}$ notopodia long and club-shaped, constricted at the base and widening distally, with internal simple notochaetae (Fig. 2A-B); C1 notopodia $2.0 \mathrm{~mm}$ in length (mean $3.0 \mathrm{~mm}$, range $2.0-4.0 \mathrm{~mm}$, $\mathrm{n}=7$ ). Neuropodia bilobed, ventral lobes medially fused after $\mathrm{C} 1$ by a thin membrane, $\mathrm{C} 1$ ventral neuropodial lobes broader than those in succeeding segments; lateral lobes of $\mathrm{C}$ neuropodia lacking dorsal and ventral cirri. Both neuropodial lobes bear a row of uncini on distal margin. $\mathrm{C} 1$ lateral lobe uncini asymmetrically pyriform to ellipsoid, apically rounded and pointed at base, widest at middle or slightly below, with curved proximal margin (Fig. 2I). C1 ventral lobe uncini long ellipsoid to D-shaped, apically blunt and pointed at base, widest at middle or slightly above (Fig. 2J).

TUBE. Tube short and curved, pale cream to tan, thin and composed of laminated proteinaceous material, externally covered in mud (Fig. 2D). 


\section{Ecology and distribution}

The new species is known only from the type locality in the lower St. Lawrence Estuary, epibenthic on fine sediments at a depth of $350 \mathrm{~m}$. Tubes resembling those of this species were also observed on bottom photographs from stations 18 and 20, at 390 and $331 \mathrm{~m}$ depth, respectively (Belley et al. 2010).
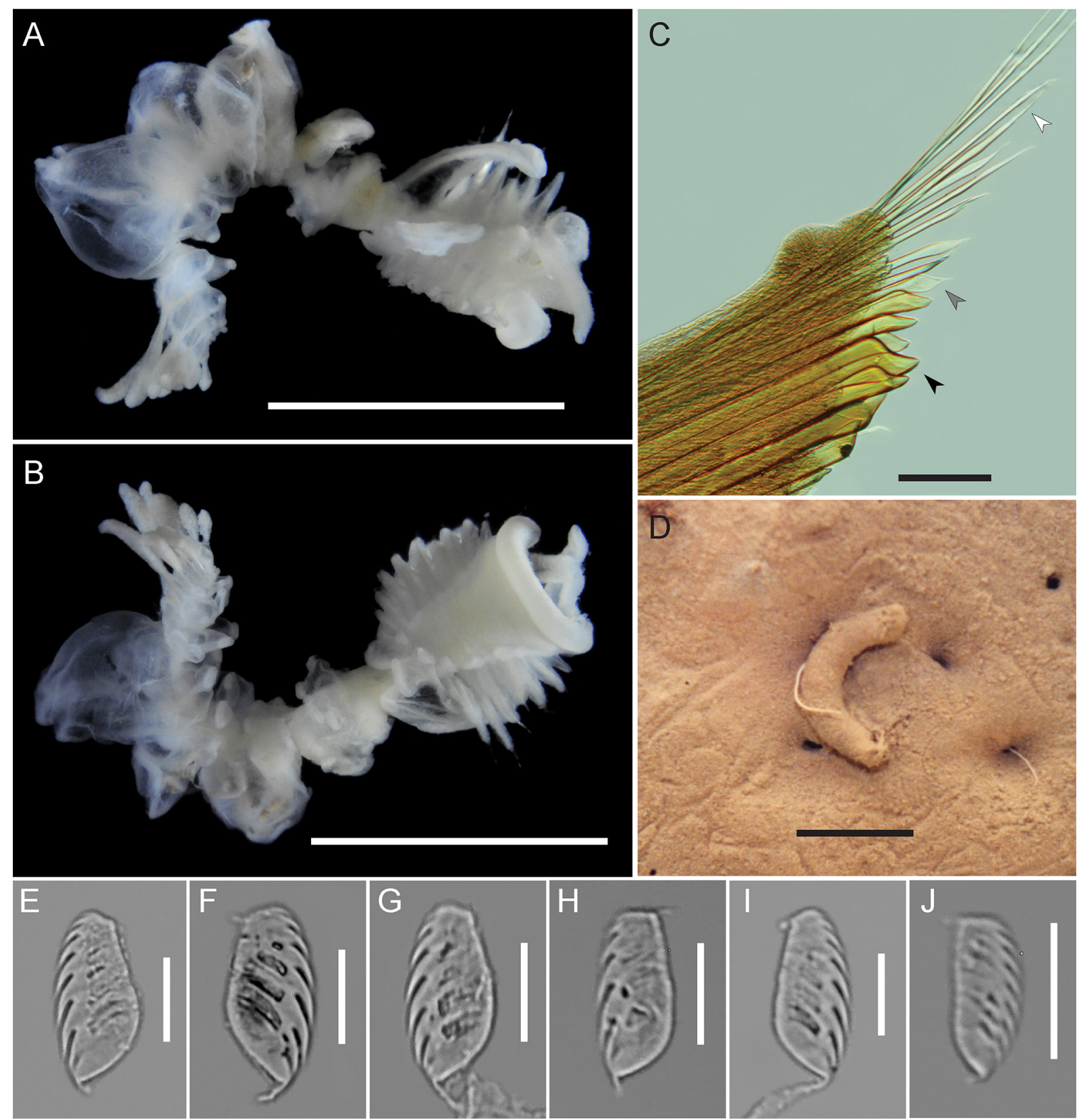

Fig. 2. Chaetopterus bruneli sp. nov. A. Latero-dorsal view of holotype CMNA 2015-0016. B. The same in ventral view. C. A4 notopodium of paratype CMNA 2015-0010; white arrow: simple terminal notochaetae, grey arrow: lanceolate simple chaetae, black arrow: stout specialised cutting chaetae. D. In situ tube of Chaetopterus bruneli sp. nov. in the St. Lawrence Estuary at a depth of $350 \mathrm{~m}$, specimen not collected. E-J. Uncini sampled from paratype specimen CMNA 2015-0018. E. Uncinus of B1 anterior neuropodial lobe. F. Uncinus of B1 posterior lobe. G. Uncinus of B3 piston torus. H. Uncinus of B3 ventral lobe. I. Uncinus of C1 lateral lobe. J. Uncinus of C1 ventral lobe. Scale bars: A-B $=5 \mathrm{~mm}$; $\mathrm{C}=200 \mu \mathrm{m} ; \mathrm{D}=1 \mathrm{~cm}$ approx.; $\mathrm{E}-\mathrm{J}=20 \mu \mathrm{m}$. 

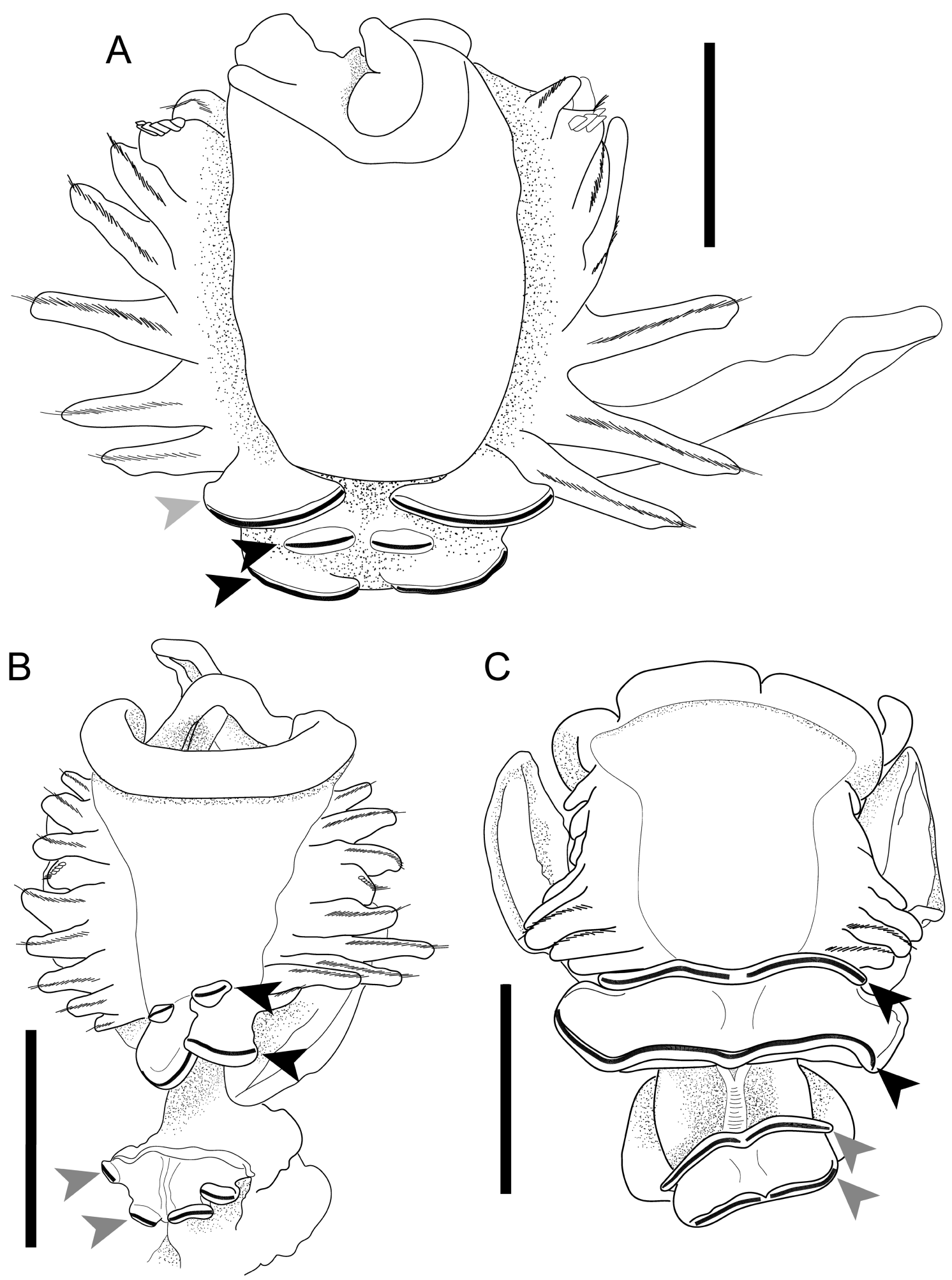

Fig. 3. Illustrated differences in A9, B1, and B2 neuropodial structures among species. A. Chaetopterus norvegicus M. Sars, 1835, paralectotype NHMO C5877, anterior ventral view to segment B1. B. Chaetopterus bruneli sp. nov., holotype CMNA 2015-0016, anterior ventral view to B2. C. Chaetopterus longipes Crossland, 1904 (UF 5920) from Japan, anterior ventral view to B2. Light grey arrows indicate segment A9 neuropodia, black arrows indicate segment B1 neuropodia, and dark grey arrows indicate segment B2. Scale bars: $2 \mathrm{~mm}$. 
In the late spring to early autumn of 1990 and 1991, several physico-chemical and biological measures were studied near the type locality of $C$. bruneli sp. nov. in the lower St. Lawrence Estuary (Station 26 in Savenkoff et al. 1994). These measurements were collected around the same time as some of the type specimens presented here. At that time, the type locality was in an upwelling area of the Laurentian trough, characterized by moderate productivity, low vertical stratification, higher salinity, and lower temperatures compared to the more productive plume region downstream (Savenkoff et al. 1994). The bottom water in the lower St. Lawrence Estuary is now being reported as increasingly and persistently hypoxic in recent years (Belley et al. 2010; Gilbert et al. 2005), which may explain why attempts to recollect this species from the type locality in September 2015 and August 2020 proved unsuccessful. Future benthic surveys of the St. Lawrence Estuary and Gulf of St. Lawrence may provide revised information about the distribution of this species.

\section{Remarks}

Chaetopterus bruneli sp. nov. is likely closely related to C. norvegicus. A summary of morphological features for both species is given in Tables 1 and 2. These species are unusual among described species of Chaetopterus for having unfused neuropodial lobes in segments B1 and B2 (see Discussion). Chaetopterus bruneli sp. nov. differs from $C$. norvegicus by its smaller body size, its lack of neuropodia in tagma A, and by its club-shaped notopodia and fewer chaetigers in tagma C. Chaetopterus bruneli sp. nov. builds mud-covered tubes on the surfaces of fine sediments at upper continental slope depths, whereas $C$. norvegicus is found in rocky areas on hard substrates at continental shelf depths, with little sediment on the external surface of the tubes.

Some characters distinguishing these species may vary ontogenetically in Chaetopterus, including the body size and the number of segments in tagma $C$. There is, however, evidence from studies on the development of Chaetopterus that the neuropodia in the anterior tagma are present one day postmetamorphosis in a species that bears these structures as adults (Irvine et al. 1999: fig. 8b). Thus, the absence of neuropodia in tagma A should be reliable for distinguishing post-settlement individuals. While no mature gonads were observed in the preserved material of $C$. bruneli sp. nov., long-term preservation in alcohol can sometimes make distinguishing fat deposits from gametes difficult in specimens of Chaetopterus. The specimens of C. bruneli sp. nov. described here were collected over several seasons over two years and do not vary substantially in their morphology, nor in size. Genetic evidence is not available, as the specimens were preserved in formalin and no new material is available for tissue collection. The morphological and ecological differences between these species outlined above are substantial enough to provide sufficient grounds for the establishment of a new species.

Only one other described species of Chaetopterus, C. longipes Crossland, 1904, lacks neuropodia in tagma A (Fig. 3C). Chaetopterus longipes was originally described from the Maldive Archipelago and was redescribed from Japanese material (Nishi 1996). Phylogenetic analyses suggest that $C$. longipes may represent a species complex distributed in both the tropical Indo-Pacific and Caribbean (Moore et al. 2017). Like C. norvegicus, $C$. longipes builds epibenthic tubes; these, however, occur gregariously and are embedded within elevated crevices on rocky coral reef substrates or found attached to the undersides of rocks rather than on the surface of soft sediments (Nishi 1996, 2001). Neither C. bruneli sp. nov. nor $C$. norvegicus are known to occur gregariously. $C$. bruneli sp. nov. lacks the fused, suckerlike neuropodia of segments B1 and B2 that are present in $C$. longipes and in most other species of Chaetopterus (Fig. 3). There are no records of any Chaetopterus species lacking neuropodia in tagma A north of $33^{\circ} \mathrm{N}$ latitude. The morphological and ecological differences among these species warrant the establishment of a distinct taxon, C. bruneli sp. nov. 
Table 2. Comparison of uncini measurements and tooth counts for Chaetopterus norvegicus M. Sars, 1835 and $C$. bruneli sp. nov.

\begin{tabular}{|c|c|c|}
\hline Neuropodial lobe & $\begin{array}{c}\text { Chaetopterus norvegicus } \\
\text { M. Sars, } 1835\end{array}$ & Chaetopterus bruneli sp. nov. \\
\hline \multicolumn{3}{|l|}{ A9 neuropodium } \\
\hline Teeth & $6-9($ mean $7.5 ; n=61)$ & absent \\
\hline Length $(\mu \mathrm{m})$ & $44.3-62.1($ mean $54.6 ; \mathrm{n}=62)$ & absent \\
\hline Width $(\mu \mathrm{m})$ & $20.4-30.4($ mean $26.4 ; \mathrm{n}=62)$ & absent \\
\hline Shape summary & pyriform to D-shaped & absent \\
\hline \multicolumn{3}{|l|}{ B1 anterior lobe } \\
\hline Teeth & $7-9($ mean $7.8 ; n=41)$ & $6-8($ mean $7.4 ; \mathrm{n}=7)$ \\
\hline Length $(\mu \mathrm{m})$ & $31.4-50.1($ mean $43.1 ; \mathrm{n}=38)$ & $38.8-42.5($ mean $40.4 ; \mathrm{n}=7)$ \\
\hline Width $(\mu \mathrm{m})$ & $18.1-24.5($ mean $21.8 ; \mathrm{n}=38)$ & $16.6-19.9($ mean $18.2 ; \mathrm{n}=7)$ \\
\hline Shape summary & ellipsoid to D-shaped & pyriform to D-shaped \\
\hline \multicolumn{3}{|l|}{ B1 posterior lobe } \\
\hline Teeth & $6-8($ mean $7.3 ; \mathrm{n}=58)$ & 5-7 (mean $6.0 ; \mathrm{n}=8)$ \\
\hline Length $(\mu \mathrm{m})$ & $44.0-60.0($ mean $50.7 ; \mathrm{n}=55)$ & $32.6-41.7($ mean $38.1 ; n=8)$ \\
\hline Width $(\mu \mathrm{m})$ & $21.1-30.0($ mean $25.7 ; \mathrm{n}=55)$ & $16.7-20.0($ mean $18.2 ; \mathrm{n}=8)$ \\
\hline Shape summary & pyriform to D-shaped & pyriform to D-shaped \\
\hline \multicolumn{3}{|l|}{ B3 lateral lobe } \\
\hline Teeth & $7-9($ mean $7.9 ; \mathrm{n}=19)$ & $5-6($ mean $5.9 ; \mathrm{n}=7)$ \\
\hline Length $(\mu \mathrm{m})$ & $27.9-34.1($ mean $30.7 ; n=16)$ & $31.3-36.0($ mean $33.8 ; n=7)$ \\
\hline Width $(\mu \mathrm{m})$ & $12.9-15.5($ mean $14.1 ; \mathrm{n}=16)$ & $14.7-17.6($ mean $16.2 ; \mathrm{n}=7)$ \\
\hline Shape summary & ellipsoid to D-shaped & ellipsoid to pyriform \\
\hline \multicolumn{3}{|l|}{ B3 ventral lobe } \\
\hline Teeth & $6-9($ mean $7.3 ; n=41)$ & $5($ mean $5 ; \mathrm{n}=2)$ \\
\hline Length $(\mu \mathrm{m})$ & $28.4-40.0($ mean $35.7 ; \mathrm{n}=42)$ & $32.9-34.8($ mean $33.8 ; \mathrm{n}=2)$ \\
\hline Width $(\mu \mathrm{m})$ & $15.1-20.7($ mean $17.7 ; \mathrm{n}=42)$ & $14.7-15.6($ mean $15.2 ; \mathrm{n}=2)$ \\
\hline Shape summary & D-shaped to pyriform & ellipsoid to pyriform \\
\hline \multicolumn{3}{|l|}{ C1 lateral lobe } \\
\hline Teeth & $6-9($ mean $7.4 ; \mathrm{n}=58)$ & $6-7($ mean $6.7 ; n=14)$ \\
\hline Length $(\mu \mathrm{m})$ & $38.8-49.3($ mean $43.9 ; \mathrm{n}=59)$ & $36.0-41.6($ mean $38.7 ; n=14)$ \\
\hline Width $(\mu \mathrm{m})$ & $18.7-25.7($ mean $21.6 ; \mathrm{n}=59)$ & $16.7-19.7($ mean $18.0 ; \mathrm{n}=14)$ \\
\hline Shape summary & D-shaped to ellipsoid & pyriform to ellipsoid \\
\hline \multicolumn{3}{|l|}{ C1 ventral lobe } \\
\hline Teeth & $8-12($ mean $10.4 ; \mathrm{n}=52)$ & $8-10($ mean $8.7 ; n=14)$ \\
\hline Length $(\mu \mathrm{m})$ & $20.4-40.5($ mean $33.3 ; \mathrm{n}=53)$ & $18.4-28.2($ mean $25.3 ; n=14)$ \\
\hline Width $(\mu \mathrm{m})$ & $7.59-14.8($ mean $12.3 ; \mathrm{n}=53)$ & $8.4-11.5($ mean $10.2 ; \mathrm{n}=14)$ \\
\hline Shape summary & ellipsoid to falcate & ellipsoid to D-shaped \\
\hline
\end{tabular}

\section{Discussion}

The unfused B1 and B2 neuropodia in Chaetopterus bruneli sp. nov. and Chaetopterus norvegicus likely represent a morphological synapomorphy and suggest a close relationship. This feature is also shared by Chaetopterus antarcticus Kinberg, 1866, described from the Straits of Magellan. In the most recent phylogeny of the family, these high latitude species, along with the unusual mesopelagic species C. pugaporcinus Osborn, Rouse, Goffredi \& Robison, 2007, were recovered in a clade sister to all other species of Chaetopterus (Moore et al. 2017), which tend to have a more shallow-water, tropical to temperate distribution. This suggests that there may have been early separate radiations into high- 
latitude and deep-water habitats and shallow tropical-temperate habitats in the evolutionary history of the genus. Further work on the phylogeny and comparative morphology in the genus may reveal additional characters separating the major clades. The preservation of material for genetic barcoding should be prioritized in future collections of $C$. bruneli sp. nov. from the type locality.

Chaetopterus bruneli sp. nov. is the northernmost record of the genus in the western Atlantic. Prior to this study, the northernmost western Atlantic records belong to Chaetopterus pergamentaceus Cuvier, 1830 from Woods Hole, Massachussetts, USA, a large, widespread, infaunal species which was originally described from the Caribbean Sea. There are currently 18 valid species within the genus Chaetopterus (Read \& Fauchald 2019; Tilic \& Rouse 2020); however, most of these were either recently described or were resurrected in a relatively recent partial revision of Pacific species (Nishi 2001). The resurrection of $C$. norvegicus presented here is a first step toward revising the taxonomy of Atlantic species of Chaetopterus. Fourteen nominal taxa remain in synonymy under the 'cosmopolitan' species C. variopedatus, originally described from the Adriatic Sea. Phylogenetic studies have shown that the true diversity of the genus Chaetopterus is under-represented in the current taxonomy (Osborn et al. 2007; Zhang et al. 2015; Moore et al. 2017). Forthcoming work will include a comprehensive revision of the genus to address the long-standing taxonomic issues.

\section{Acknowledgements}

Specimens of this newly described species were obtained as a result of the study of deep-water benthic communities from the St. Lawrence Estuary in mesocosms. This work was supported by the Department of Fisheries \& Oceans Canada (Institut Maurice-Lamontagne, Mont-Joli). This material is based upon work supported by the National Science Foundation Graduate Research Fellowship under Grant No. DGE-1315138, and a Smithsonian Predoctoral Fellowship, both awarded to J.M.M. We thank G. Paulay, R. Anderson, and two anonymous reviewers for helpful comments on the manuscript. We are grateful to L. Harris (Los Angeles County Museum of Natural History), K. Osborn (Smithsonian National Museum of Natural History), Y. Dare (Canadian Museum of Nature), A.M. Bemis and J.S. Slapcinsky (Florida Museum of Natural History), T.H. Struck (University of Oslo) Natural History Museum, and the Norwegian Barcode of Life initiative (NorBOL) for providing access to specimens, sequence data, or documentation. We are also grateful to $\mathrm{L}$. Beaudin for his continued support during the mesocosm experiments, and for his help in collecting and processing sediment samples from which the specimens of this new species were obtained.

\section{References}

Belley R., Archambault P., Sundby B., Gilbert F. \& Gagnon J.-M. 2010. Effects of hypoxia on benthic macrofauna and bioturbation in the Estuary and Gulf of St. Lawrence, Canada. Continental Shelf Research 30: 1302-1313. https://doi.org/10.1016/j.csr.2010.04.010

Berrill N.J. 1928. Regeneration in the polychaet Chaetopterus variopedatus. Journal of the Marine Biological Association of the United Kingdom 15:151-158. https://doi.org/10.1017/S0025315400055594

Britayev T.A. \& Martin D. 2019. Chaetopteridae Audouin \& Milne-Edwards, 1833. In: Purschke G., Böggemann M. \& Westheide W. (eds) Annelida: Volume 1: Annelida Basal Groups and Pleistoannelida, Sedentaria I: 156-171. De Gruyter, Berlin and Boston.

Crossland C. 1904. The Polychaeta of the Maldive Archipelago from the collections made by J. Stanley Gardiner in 1899. Proceedings of the Zoological Society of London 1: 270-286.

https://doi.org/10.1111/j.1469-7998.1904.tb08291.x

Danielssen D.C. 1861. Beretning om en zoologisk Reise foretagen i Sommeren 1857. Nyt Magazin for Naturvidenskaberne 11: 1-58. 
de St. Joseph A.A. 1894. Les Annélides polychètes des côtes de Dinard. Troisième Partie. Annales des sciences naturelles, Paris, Série 7 17: 1-395.

Fauvel P. 1927. Polychètes sédentaires. Addenda aux Errantes, Archiannélides, Myzostomaires. Faune de France 16: 1-494.

GBIF 2019. Chaetopterus norvegicus M. Sars, 1835. GBIF Backbone Taxonomy. Checklist Data Set. Available from https://www.GBIF.org [accessed 12 May 2020].

Gilbert D., Sundby B., Gobeil C., Mucci A. \& Tremblay G.-H. 2005. A seventy-two-year record of diminishing deep-water oxygen in the St. Lawrence estuary: The northwest Atlantic connection. Limnology and Oceanography 50: 1654-1666. https://doi.org/10.4319/lo.2005.50.5.1654

Irvine S.Q., Chaga O. \& Martindale M.Q.1999. Larval ontogenetic stages of Chaetopterus: Developmental heterochrony in the evolution of chaetopterid polychaetes. Biological Bulletin 197: 319-331.

https://doi.org/10.2307/1542786

Jensen A. \& Frederiksen R. 1992. The fauna associated with the bank-forming deepwater coral Lophelia pertusa (Scleractinaria) on the Faroe shelf. Sarsia 77: 53-69.

https://doi.org/10.1080/00364827.1992.10413492

Joyeux-Laffuie J. 1890. Étude monographique du Chétoptere (Chaetopterus variopedatus, Rénier) suivie d'une révision des espèces du genre Chaetopterus. Archives de zoologie expérimentale et générale série 2 8: 245-360.

Lo Bianco S. 1893. Gli anellidi tubicoli trovati nel Golfo di Napoli. Atti Della R. Accademia delle Scienze Fisiche e Matematiche 5: 1-97.

Malmgren A. J. 1867. Annulata Polychaeta Spetsbergice, Groenlandice, Islandice et Scandinavice. Hactenus Cognita. Ex Officina Frenckelliana, Helsingforslæ.

McIntosh W.C. 1857. The Marine Invertebrates and Fishes of St. Andrews. Taylor \& Francis, London.

McIntosh W.C. 1915. Chaetopteridae. A Monograph of the British Marine Annelids: 115-132. The Ray Society, London.

Meneghini G. \& Renier S.A. 1847. Osservazioni postume de zoologia Adriatica. I.R. Istituto Veneto di Scienze, Lettere ed Arti, Venice, Italy.

Moore J.M., Nishi E. \& Rouse G.W. 2017. Phylogenetic analyses of Chaetopteridae (Annelida). Zoologica Scripta 46: 596-610. https://doi.org/10.1111/zsc.12238

Nishi E. 1996. Dense aggregation of Chaetopterus longipes Crossland, 1904 (Chaetopteridae, Polychaeta) in coral reefs at Okinawa, Japan. Natural History Research 4: 41-47.

https://doi.org/10.13140/2.1.3180.0005

Nishi E. 2001. Partial revision of Japanese Chaetopterus (Chaetopteridae, Polychaeta), including description of three new species from southern Pacific side of central Japan. Actinia 14: 1-26.

Ørsted A.S. 1844. De regionibus marinis. Elementa topographiae historiconaturalis freti Öresund. J.C. Sharling, Copenhagen.

Ørsted A.S. 1845. Fortegnelse over Dyr, samlede i Christianiafjord ved Drøbak fra 21-24 Juli, 1844. Naturhistorisk tidsskrift, Kjøbenhavn 2: 400-427.

Osborn K.J., Rouse G.W., Goffredi S.K. \& Robison B.H. 2007. Description and relationships of Chaetopterus pugaporcinus, an unusual pelagic polychaete (Annelida, Chaetopteridae). Biological Bulletin 212: 40-54. https://doi.org/10.2307/25066579 
Quatrefages A. 1866. Annélides et Géphyriens. Histoire naturelle des Annelés marins et d'eau douce. Annélides et Géphyriens. Volume 2. Première partie. Librairie encyclopédique de Roret, Paris.

Read G. \& Fauchald K. 2019. World Polychaeta Database. Chaetopteridae Audouin \& Milne Edwards, 1833. World Register of Marine Species.

Available from http://www.marinespecies.org/aphia.php?p=taxdetails\&id=918 [accessed 12 May 2020].

Renier S.A. 1804. Prospetto della Classe dei Vermi, nominati el ordinati secondo il Sistemo de Bosc. $X V-X X V I I I$. Padua.

Sars G.O. 1873. Bidrag til Kundskab om Christianiafjordens Fauna. J. Dahl, Christiania.

Sars M. 1835. Beskrivelser og Iagttagelser over nogle morkelige eller nye $i$ havet ved den bergenske kyst levende dyr af polypernes, acalephernes, radiaternes, annelidernes, og molluskerns classer, med en kort oversigt over de hidtil af forfattern sammesteds fundne arter og deres forkommen. Thorstein Hallagers Forlag hos Chr., Bergen.

Sars M. 1860. Uddrag af en Beskrivelse over Chaetopterus sarsii n.sp., og Chaetopterus norvegicus Sars. Forhandlinger fra Videnskabs-Selskabet i Christiania 1860: 85-88.

Sars M. ca 1870. Unpublished figures of Chaetopterus sarsii and Chaetopterus norvegicus. MS fol. 2145 III, kapsel 1. Håndskriftsamlingen, Universitetsbiblioteket i Oslo Nasjonalbiblioteket, Norway.

Savenkoff C., Comeau L., Vézina A.F. \& Gratton Y. 1994. Seasonal Variation of the Biological Activity in the Lower St. Lawrence Estuary. Canadian Technical Report of Fisheries and Aquatic Sciences 2006, Marine Environmental Sciences Branch, Mont joli (Québec).

Silverberg N., Gagnon J.-M. \& Lee K. 1995. A benthic mesocosm facility for maintaining soft-bottom sediments. Netherlands Journal of Sea Research 34: 289-302. https://doi.org/10.1016/0077-7579(95)90039-X

Tilic E. \& Rouse G.W. 2020. Hidden in plain sight, Chaetopterus dewysee sp. nov. (Chaetopteridae, Annelida) - A new species from Southern California. European Journal of Taxonomy 643: 1-16. https://doi.org/10.5852/ejt.2020.643

Zhang Y., Rouse G.W. \& Qiu J.-W. 2015. A new species of Mesochaetopterus (Annelida, Chaetopteridae) from Hong Kong with comments on the phylogeny of the family. Zootaxa 3974: 495-506.

https://doi.org/10.11646/zootaxa.3974.4.2

Manuscript received: 22 June 2020

Manuscript accepted: 3 August 2020

Published on: 6 October 2020

Topic editor: Rudy C.A.M. Jocqué

Desk editor: Kristiaan Hoedemakers

Printed versions of all papers are also deposited in the libraries of the institutes that are members of the EJT consortium: Muséum national d'histoire naturelle, Paris, France; Meise Botanic Garden, Belgium; Royal Museum for Central Africa, Tervuren, Belgium; Royal Belgian Institute of Natural Sciences, Brussels, Belgium; Natural History Museum of Denmark, Copenhagen, Denmark; Naturalis Biodiversity Center, Leiden, the Netherlands; Museo Nacional de Ciencias Naturales-CSIC, Madrid, Spain; Real Jardín Botánico de Madrid CSIC, Spain; Zoological Research Museum Alexander Koenig, Bonn, Germany; National Museum, Prague, Czech Republic. 